\title{
SNHS Resolutions, October 18, 1969
}

1. Whereas the government of Ontario has acted wisely to place a ban, with some exceptions, on the use of DDT in that province, and

Whereas this action was a very courageous one for that government in view of the quantities of agricultural pesticides used in the province and the consequent pressure on the Government of Ontario to continue to permit the use of DDT,

BE IT RESOLVED that the Saskatchewan Natural History Society send our congratulations and expression of appreciation to the Government of Ontario for its recent action in this regard.

2. Whereas DDT has been clearly implicated in the decline of several species of birds, and

Whereas the use of DDT has been shown to have detrimental effects on the fishing industry of Eastern Canada, and

Whereas the long range effects of the present DDT intake on human biology is unknown and perhaps detrimental, and

Whereas various governments and agencies are becoming increasingly aware of the detrimental effects of non-biodegradeable pesticides and are taking or have taken action to ban its use, therefore

BE IT RESOLVED that the Saskatchewan Natural History Society form a committee to assemble documentation concerning the adverse effects of DDT and other non-biodegradeable pesticides in our environment and present this documentation to the Government of Saskatchewan and to the Government of Canada with a request that these governments ban the use of DDT and other non-biogradeable pesticides within their jurisdiction.

3. Whereas the Blue Jay Bookshop is a major source of income to our Society while providing a real service to its members,

BE IT RESOLVED that Frank Brazier receive our hearty thanks for his continued time-consuming and dedicated effort on our behalf.

4. BE IT RESOLVED that the Saskatchewan Natural History Society extend congratulations to the R.M. of Torch River for showing genuine concern for the preservation of Kelsey Lake.

5. Whereas Kelsey Lake is a shallow marsh supporting bird and animal life of value to the people in the area, and

Whereas the lake is of value for flood control and the maintenance of ground water,

BE IT RESOLVED that the Government of Saskatchewan be asked to preserve this area.

6. Whereas the Saskatchewan Natural History Society had a successful summer meeting in June 1969 in the beautiful grasslands of the Val Marie country, where the characteristic flora and fauna of the river breaks and hills were studied with great interest by members from parts of the province unfamiliar with this distinctive habitat, and

Whereas several unusual species of flora and fauna were recorded including the Oxytropis besseyi and the Violet-green Swallow (see Blue Jay, $27: 144-45$, for the first nesting record for the province), and

Whereas the Society at this time formally unveiled the prairie stone cairn marking its Prairie Dog Sanctuary, where protection is offered to this unique wildlife species under arrangements made possible by the co-operation of the Department of Natural Resources, and 
Whereas the Society was honoured by the presence at the meeting of the M.L.A. for Shaunavon, the Honorable F. Larochelle, who spoke for the Government in the unveiling of the cairn, and

Whereas we were reminded on this gratifying and pleasant official occasion of the co-operation which has existed between our Society and the Department of Natural Resources in mutual concern for the protection of grassland species,

BE IT RESOLVED that an expression of thanks be made to the Government of Saskatchewan for their co-operation in bringing this sanctuary into being, and

BE IT FURTHER RESOLVED that the Government of Saskatchewan be urged to give all possible support to the proposed creation of a park preserving that remarkably interesting portion of our grasslands in the Southwest.

7. Whereas the indiscriminate and wholesale clearing of some areas designated as Community Pastures has many detrimental effects, including the following:

a) destroys the ecological balance of the whole area

b) has been detrimental to the wildlife and general appearance of the area

c) accentuates the flooding problem in adjacent areas

d) destroys natural shelter for cattle

BE IT RESOLVED that before any such clearing is proceeded with by P.F.R.A. or other government agencies a study be made so that a percentage of tree growth remains undisturbed, after giving due consideration to such factors as location, soil fertility, scenic, aesthetic and wildlife values, and providing natural shelter for the cattle.

8. Whereas the Regina Waterfowl Park is being encroached upon by the developing city, and

Whereas this unique waterfowl area within the city limits is of inestimable value to the city and the university, therefore

BE IT RESOLVED that the City of Regina, the Wascana Center Authority and the Canadian Wildlife Service be asked to extend the Sanctuary to include the marsh area east of the bypass.

9. Whereas the new Condie Nature Interpretative Center combines the preservation of valuable marsh habitat with enlightened and indeed inspired conservation education with at the same time potential as a major tourist attraction, therefore

BE IT RESOLVED that the Government of Saskatchewan and its Department of Natural Resources be commended for providing this important facility. In particular we would like to commend $\mathrm{Mr}$. Fred Bard, Director of the Saskatchewan Museum of Natural History, for his foresight and leadership in making this centre a reality.

10. Whereas the proposed Indian Lake hydro development in Manitoba would have interfered with the livelihood of the local Indian population, would have been detrimental to the preservation of invaluable flora and fauna in the region and would have destroyed one of the finest tourist attractions in the Province of Manitoba, therefore

BE IT RESOLVED that the Government of Manitoba be commended for discontinuing action on this project. 